\title{
European cowpea landraces for a more sustainable agriculture system and novel foods
}

\author{
Márcia Carvalho, ${ }^{\mathrm{a}}$ Penelope J Bebeli, ${ }^{\mathrm{b}^{*}} \odot$ Graça Pereira, $^{\mathrm{c}}$ Isaura Castro, ${ }^{\mathrm{a}, \mathrm{d}}$

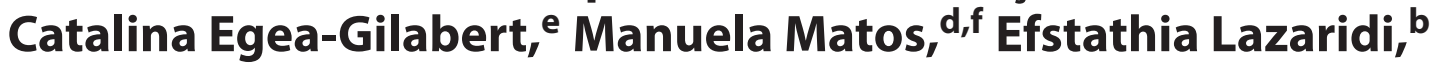 \\ Isabel Duarte, ${ }^{\mathrm{c}}$ Teresa Lino-Neto, ${ }^{\mathrm{g}}$ Georgia Ntatsi, ${ }^{\mathrm{b}}$ Miguel Rodrigues, ${ }^{\mathrm{h}} \odot$ \\ Dimitrios Savvas, ${ }^{b}$ Eduardo Rosa $^{a}$ and Valdemar Carnide ${ }^{a, d}$
}

\begin{abstract}
BACKGROUND: Genetic diversity is fundamental to breeding programs and consequently has an important role in obtaining new varieties. To properly use the genetic diversity present in germplasm collections, a good knowledge of the agro-morphological traits of each accession is needed. The aim of this study was to explore the production capacity of 24 cowpea landraces from southern Europe, through phenotypic characterization and evaluation in three different locations in Greece and Portugal.

RESULTS: Most qualitative parameters tested showed a high stability among the three locations. A wide difference was observed among the three locations with respect to number of days to flowering, ranging from 55 to 99 days. Quantitative traits showed a higher genotype $\times$ environment than genetic variance component. In general, an inverse relationship between $\sigma^{2}{ }_{\text {ge }} / \sigma^{2}{ }_{g}$ ratio (where $\sigma_{\text {ge }}^{2}$ is genotype $\times$ genotype interaction and $\sigma_{g}^{2}$ is genotype impact) and heritability value was observed. Principal component analysis was able to group accessions based on their origin. The first two principal components explained $97.52 \%$ of variation, being the number of seeds per plant, plant height and seed protein content, the traits which contributed most to variability.
\end{abstract}

CONCLUSION: The results show that sufficient variation exists in different traits within landraces in the studied cowpea germplasm to pursue a breeding program. However, the quantitative traits showed a higher genotype $\times$ environment component.

() 2017 Society of Chemical Industry

Keywords: Vigna unguiculata L. Walp; G $\times$ E interaction; landraces; qualitative traits; quantitative traits

\section{INTRODUCTION}

Cowpea (Vigna unguiculata (L.) Walp.) is a primarily self-pollinated species of the genus Vigna, a member of the Leguminosae family. Different areas have been proposed as cowpea domestication centers, ${ }^{1,2}$ although it is unquestionably of African origin. ${ }^{3}$ Introduction of cowpea in Europe has been reported to occur throughout the eastern part of the Mediterranean Basin, as it was certainly cultivated by the Romans in the first century AD., This grain legume is cultivated in many tropical and subtropical regions of the world. ${ }^{6}$

Nowadays, cowpea is cultivated on a small scale in southern European countries, representing only $0.43 \%$ of the total cowpea seed production, amounting to 5.59 million tonnes in 2014 . $^{7}$ Cowpea is mainly used in the human diet but also as forage for animal feeding. It is mainly cultivated for its dry grain, although in some regions young leaves, fresh pods and fresh seeds are also consumed, ${ }^{8}$ constituting a significant source of proteins, essential amino acids, minerals, vitamins and fiber. ${ }^{9,10}$

Agricultural productivity of food legumes, grown in semi-arid areas or drylands, e.g. the Mediterranean Basin, is usually characterized by instability, as it is influenced by several environmental constraints, such as water scarcity and extreme temperatures ${ }^{11,12}$ that prevail in these areas. ${ }^{13}$ Tolerance to low water regimes and
* Correspondence to: PJ Bebeli, Laboratory of Plant Breeding and Biometry, Department of Crop Science, Agricultural University of Athens, lera Odos 75, 118 55 Athens, Greece. E-mail: bebeli@aua.gr

a Centre for the Research and Technology of Agro-Environment and Biological Sciences (CITAB), University of Trás-os-Montes and Alto Douro (UTAD), Vila Real, Portugal

b Department of Crop Science, Agricultural University of Athens, Athens, Greece

c National Institute for Agrarian and Veterinarian Research IP (INIAV), Elvas, Portugal

d Department of Genetics and Biotechnology, University of Trás-os-Montes and Alto Douro (UTAD), Vila Real, Portugal

e Department of Agrarian Science and Technology, Technical University of Cartagena, Cartagena, Spain

f Biosystems and Integrative Sciences Institute (BiolSI), Sciences Faculty, University of Lisbon, Lisbon, Portugal

g BioSystems and Integrative Sciences Institute (BiolSI), Plant Functional Biology Centre, University of Minho, Braga, Portugal

h Animal and Veterinary Research Centre (CECAV), University of Trás-os-Montes and Alto Douro (UTAD), Vila Real, Portugal 


\begin{tabular}{|c|c|c|c|c|c|}
\hline Country of origin & Code & Latitude & Longitude & Altitude (m) & Breeding status \\
\hline \multirow[t]{18}{*}{ Portugal } & Cp4906 & $40^{\circ} 00^{\prime} 28^{\prime \prime} \mathrm{N}$ & $8^{\circ} 27^{\prime} 04^{\prime \prime} \mathrm{W}$ & 198 & Landrace \\
\hline & Cp5128 & $39^{\circ} 59^{\prime} 11^{\prime \prime} \mathrm{N}$ & $7^{\circ} 26^{\prime} 39^{\prime \prime} \mathrm{W}$ & 402 & Landrace \\
\hline & Cp5129 & $39^{\circ} 59^{\prime} 11^{\prime \prime} \mathrm{N}$ & $7^{\circ} 26^{\prime} 39^{\prime \prime} \mathrm{W}$ & 402 & Landrace \\
\hline & Cp5131 & $39^{\circ} 59^{\prime} 11^{\prime \prime} \mathrm{N}$ & $7^{\circ} 26^{\prime} 39^{\prime \prime} \mathrm{W}$ & 402 & Landrace \\
\hline & Cp5553 & $39^{\circ} 48^{\prime} 02^{\prime \prime} \mathrm{N}$ & $8^{\circ} 06^{\prime} 03^{\prime \prime} \mathrm{W}$ & 226 & Landrace \\
\hline & Cp5556 & $37^{\circ} 47^{\prime} 15^{\prime \prime} \mathrm{N}$ & $7^{\circ} 43^{\prime} 32^{\prime \prime} \mathrm{W}$ & 160 & Landrace \\
\hline & Cp5647 & $39^{\circ} 27^{\prime} 58^{\prime \prime} \mathrm{N}$ & $7^{\circ} 56^{\prime} 14^{\prime \prime} \mathrm{W}$ & 281 & Landrace \\
\hline & Cp5648 & $39^{\circ} 27^{\prime} 53^{\prime \prime} \mathrm{N}$ & $8^{\circ} 02^{\prime} 44^{\prime \prime} \mathrm{W}$ & 45 & Landrace \\
\hline & Vg50 & $40^{\circ} 51^{\prime} 15^{\prime \prime} \mathrm{N}$ & $7^{\circ} 08^{\prime} 22^{\prime \prime} \mathrm{W}$ & 523 & Landrace \\
\hline & Vg52 & $40^{\circ} 48^{\prime} 45^{\prime \prime} \mathrm{N}$ & $7^{\circ} 23^{\prime} 26^{\prime \prime} \mathrm{W}$ & 770 & Landrace \\
\hline & Vg56 & $41^{\circ} 44^{\prime} 38^{\prime \prime} \mathrm{N}$ & $7^{\circ} 38^{\prime} 57^{\prime \prime} \mathrm{W}$ & 673 & Landrace \\
\hline & Vg59 & $40^{\circ} 14^{\prime} 57^{\prime \prime} \mathrm{N}$ & $7^{\circ} 17^{\prime} 22^{\prime \prime} \mathrm{W}$ & 507 & Landrace \\
\hline & $\operatorname{Vg} 60$ & $40^{\circ} 22^{\prime} 00^{\prime \prime} \mathrm{N}$ & $7^{\circ} 15^{\prime} 32^{\prime \prime} \mathrm{W}$ & 633 & Landrace \\
\hline & Vg65 & $41^{\circ} 19^{\prime} 25^{\prime \prime} \mathrm{N}$ & $7^{\circ} 28^{\prime} 04^{\prime \prime} \mathrm{W}$ & 766 & Landrace \\
\hline & Vg67 & $41^{\circ} 17^{\prime} 52^{\prime \prime} \mathrm{N}$ & $7^{\circ} 05^{\prime} 53^{\prime \prime} \mathrm{W}$ & 247 & Landrace \\
\hline & Vg72 & $41^{\circ} 16^{\prime} 57^{\prime \prime} \mathrm{N}$ & $6^{\circ} 35^{\prime} 06^{\prime \prime} \mathrm{W}$ & 726 & Landrace \\
\hline & Vg73 & $41^{\circ} 27^{\prime} 19^{\prime \prime} \mathrm{N}$ & $7^{\circ} 00^{\prime} 30^{\prime \prime} \mathrm{W}$ & 750 & Landrace \\
\hline & Fradel & & & & Variety \\
\hline \multirow[t]{5}{*}{ Spain } & BGE022146 & $37^{\circ} 00^{\prime} 35^{\prime \prime} \mathrm{N}$ & $3^{\circ} 00^{\prime} 26^{\prime \prime} \mathrm{W}$ & 1082 & Landrace \\
\hline & BGE038474 & $36^{\circ} 31^{\prime} 47^{\prime \prime} \mathrm{N}$ & $5^{\circ} 15^{\prime} 26^{\prime \prime} \mathrm{W}$ & 225 & Landrace \\
\hline & BGE038477 & $36^{\circ} 36^{\prime} 51^{\prime \prime} \mathrm{N}$ & $5^{\circ} 08^{\prime} 53^{\prime \prime} \mathrm{W}$ & 769 & Landrace \\
\hline & BGE038478 & $36^{\circ} 37^{\prime} 37^{\prime \prime} \mathrm{N}$ & $5^{\circ} 10^{\prime} 11^{\prime \prime} \mathrm{W}$ & 622 & Landrace \\
\hline & BGE038479 & $36^{\circ} 37^{\prime} 37^{\prime \prime} \mathrm{N}$ & $5^{\circ} 10^{\prime} 11^{\prime \prime} \mathrm{W}$ & 622 & Landrace \\
\hline Nigeria & IT97K-499-35 & & & & Breeding line \\
\hline
\end{tabular}

adaptation to high temperatures make cowpea an important crop for southern European countries; thus it is considered one of the most drought-tolerant crops. ${ }^{11,14}$ Furthermore, cowpea capacity to establish symbiosis with rhizobia and mycorrhizal fungi allows it to grow in low-fertility soils, reducing or even eliminating the need for application of inorganic fertilizers, thus resulting in a more environmentally sustainable culture as well as rendering it one of the soil fertility-restoring crops. ${ }^{9,15}$

Cowpea cultivation in southern Europe depends to an extent on a remarkable number of cowpea landraces that constitute a valuable genetic material for breeding programs. ${ }^{16,17}$ They possess significant phenotypic variability and some have developed the capacity to tolerate biotic and abiotic stresses, and thus are used in agricultural systems with low inputs and high yield stability. ${ }^{18,19}$ Based on the landraces that still preserve high genetic variability in traits related to tolerance/resistance to certain abiotic and biotic factors, and high nutritional value, it is possible to establish a cowpea breeding strategy to obtain more productive and nutritious varieties. The implementation of these breeding programs will be of great importance for Europe, which is a major importer of grain legumes such as cowpea, 10501 tonnes of dry cowpea having been imported in 2015 by the European Union. ${ }^{20}$

Availability, identification and characterization of plant genetic resources are fundamental to knowing the diversity present in the original material and the best way of undertaking a breeding program. Traditionally, the first step in studies of diversity and genetic relationships is to measure the variation in qualitative traits (such as growth habit and pattern, flower and seed color) and quantitative agronomic traits (such as number of pods per plant, number of seeds per plant and seed weight). Regarding cowpea, in recent years several studies have been carried out on morphological and agronomical characterization..$^{4,21-25}$ In these studies a high level of variability between and even within cowpea landraces has been verified, which may be useful for breeding programs. However, a large amount of the European cowpea genetic material remains unexplored and unutilized by breeding programs. For this purpose, the main objective of this study was to explore, characterize and evaluate cowpea landraces originating from two southern European countries, grown in three different locations, aiming to enlarge the genetic diversity used in modern breeding programs.

\section{MATERIALS AND METHODS}

\section{Plant material and experimental design}

Twenty-two landraces, one variety and a reference breeding line (IT97K-499-35) of Vigna unguiculata cv.-gr. unguiculata (Table 1) were subjected to agronomical and morphological characterization in three different locations in southern Europe: the Agricultural University of Athens (AUA), Athens, Greece $\left(37^{\circ} 59^{\prime} \mathrm{N}, 23^{\circ}\right.$ $42^{\prime}$ E, $\left.24 \mathrm{~m}\right)$; the National Institute for Agrarian and Veterinarian Research (INIAV), Elvas, Portugal ( $\left.38^{\circ} 53^{\prime} \mathrm{N}, 07^{\circ} 09^{\prime} \mathrm{W}, 208 \mathrm{~m}\right)$; and the University of Trás-os-Montes and Alto Douro (UTAD), Vila Real, Portugal $\left(41^{\circ} 17^{\prime} \mathrm{N}, 07^{\circ} 44^{\prime} \mathrm{W}, 465 \mathrm{~m}\right)$, during spring-summer 2014. Sowing took place on 23 May in AUA, on 29 April in INIAV and on 9 May in UTAD.

In AUA the soil was clay loam of $\mathrm{pH}\left(\mathrm{H}_{2} \mathrm{O}\right) 7.7$ and humus content of $6.3 \mathrm{~g} \mathrm{~kg}^{-1}$. In INIAV, the soil was classified as sandy clay loam with a medium texture and presented $1.0 \mathrm{~g} \mathrm{~kg}^{-1}$ humus content, $>200 \mathrm{mg} \mathrm{kg}^{-1} \mathrm{P}_{2} \mathrm{O}_{5},>200 \mathrm{mg} \mathrm{kg}-1 \mathrm{~K}_{2} \mathrm{O}_{2}$ and $\mathrm{pH}\left(\mathrm{H}_{2} \mathrm{O}\right)$ 5.2. The soil in UTAD was classified as lime with a medium texture and presented $1.3 \mathrm{~g} \mathrm{~kg}^{-1}$ humus content, $91.0 \mathrm{mg} \mathrm{kg}^{-1} \mathrm{P}_{2} \mathrm{O}_{5}$, $158.0 \mathrm{mg} \mathrm{kg}^{-1} \mathrm{~K}_{2} \mathrm{O}_{2}$ and $\mathrm{pH}\left(\mathrm{H}_{2} \mathrm{O}\right)$ 4.7. Before sowing, the experimental field was ploughed with a rotary tiller and supplied with 


\begin{tabular}{|c|c|c|c|c|}
\hline \multirow[b]{2}{*}{ Location/month } & \multicolumn{3}{|c|}{ Temperature $\left({ }^{\circ} \mathrm{C}\right)$} & \multirow[b]{2}{*}{ Precipitation $(\mathrm{mm})$} \\
\hline & Mean & Max. & Min. & \\
\hline \multicolumn{5}{|l|}{ AUA } \\
\hline April & 15.2 & 26.9 & 9.1 & 39.0 \\
\hline May & 17.1 & 32.5 & 12.7 & 2.0 \\
\hline June & 21.5 & 38.8 & 16.8 & 10.6 \\
\hline July & 24.7 & 36.6 & 21.6 & 0.0 \\
\hline August & 24.2 & 38.6 & 21.9 & 0.0 \\
\hline September & 24.5 & 33.8 & 15.7 & 20.8 \\
\hline \multicolumn{5}{|l|}{ INIAV } \\
\hline April & 16.3 & 22.7 & 9.9 & 90.0 \\
\hline May & 19.7 & 28.1 & 11.4 & 23.8 \\
\hline June & 19.2 & 26.9 & 11.6 & 1.5 \\
\hline July & 24.9 & 34.5 & 15.3 & 4.3 \\
\hline August & 25.0 & 34.7 & 15.3 & 0.0 \\
\hline September & 22.5 & 29.5 & 15.5 & 80.4 \\
\hline \multicolumn{5}{|l|}{ UTAD } \\
\hline April & 13.9 & 19.9 & 8.9 & 44.7 \\
\hline May & 14.8 & 21.6 & 8.8 & 28.5 \\
\hline June & 17.5 & 24.4 & 11.9 & 26.5 \\
\hline July & 20.6 & 27.8 & 14.5 & 29.3 \\
\hline August & 20.3 & 27.9 & 14.2 & 0.4 \\
\hline September & 17.8 & 24.0 & 13.6 & 89.3 \\
\hline
\end{tabular}

mineral fertilizer $600 \mathrm{~kg} \mathrm{ha}^{-1}$ NPK 11:15:15 in AUA, $250 \mathrm{~kg} \mathrm{ha}^{-1}$ NPK 15:15:15 in INIAV and $5700 \mathrm{~kg} \mathrm{ha}^{-1}$ limestone in UTAD.

Twelve plants per accession were grown in a greenhouse for 2 weeks in AUA. The seedlings were then transplanted in the field and the plants were spaced at $50 \mathrm{~cm}$ from row to row and $20 \mathrm{~cm}$ apart within the row and drip irrigated. In INIAV and UTAD, 20 seeds per accession were directly sown in plots of $3.75 \mathrm{~m}^{2}$ and plants were spaced at $75 \mathrm{~cm}$ from row to row and $25 \mathrm{~cm}$ apart within the row. In INIAV the accessions were drip irrigated, whereas in UTAD they were irrigated along grooves.

A randomized complete block experimental design (RCBD) was used in AUA with four replicates and three plants per replicate per accession. In INIAV and UTAD a completely randomized experimental design was implemented and 12 plants of each accession were randomly selected. During the growing season, weeds were hand-controlled and incidences of pests and diseases were handled through chemical management in all locations.

\section{Climate data}

Altitude of locations ranged from 24 m (AUA) to 465 m (UTAD), and differed mainly regarding their average mean air temperature $\left({ }^{\circ} \mathrm{C}\right)$ and precipitation $(\mathrm{mm})$. The average maximum $\left(T_{\max }\right)$ and minimum $\left(T_{\min }\right)$ air temperature $\left({ }^{\circ} \mathrm{C}\right)$ and total rainfall $(\mathrm{mm})$ per month (from April to September) were recorded at weather stations located at each experimental location (Table 2).

\section{Morphological and agronomical traits}

A total number of 14 qualitative and quantitative traits were analyzed in the three experimental locations according to IBPGR descriptors. ${ }^{26}$ Regarding qualitative traits, growth habit, flower color, seed color and shape, and eye color were recorded in all plants of each accession used in each location. Regarding
Table 3. Frequencies (\%) of the five qualitative traits studied, presented separately in the three locations, for the 24 cowpea accessions

\begin{tabular}{|llccc|}
\hline \multirow{3}{*}{ Qualitative trait } & & \multicolumn{3}{c}{ Frequency (\%) } \\
\cline { 2 - 5 } Growth habit & Class & AUA & INIAV & UTAD \\
& Erect & 47.40 & 16.67 & 86.90 \\
& Semi-erect & 12.30 & 79.17 & 13.10 \\
& Intermediate & 7.80 & 0.00 & 0.00 \\
& Semi-prostate & 32.50 & 4.16 & 0.00 \\
Flower color & White & 78.90 & 78.20 & 78.20 \\
& Violet & 9.20 & 21.80 & 21.20 \\
& Mauve-pink & 11.90 & 0.00 & 0.00 \\
& Beige & 11.50 & 17.40 & 13.10 \\
& Brown & 14.00 & 0.00 & 8.70 \\
& Cream & 63.00 & 78.30 & 73.90 \\
& Other & 11.50 & 4.30 & 4.30 \\
& Eye absent & 24.00 & 26.10 & 13.10 \\
& Black & 44.00 & 43.50 & 43.50 \\
& Brown splash or gray & 0.00 & 0.00 & 4.30 \\
& Green & 0.00 & 0.00 & 8.70 \\
& Tan brown & 24.50 & 30.40 & 30.40 \\
& Other & 7.50 & 0.00 & 0.00 \\
& Crowder & 0.00 & 0.00 & 0.00 \\
Seed shape & Globose & 4.00 & 4.30 & 13.10 \\
& Kidney & 67.50 & 82.60 & 56.50 \\
& Ovoid & 12.00 & 0.00 & 8.70 \\
& Rhomboid & 16.50 & 13.10 & 21.70 \\
& & & & \\
& & &
\end{tabular}

quantitative traits studied, plant height $(\mathrm{cm})$, first pod height (cm), number of pods, number of seeds and seed weight per plant (g) were recorded in 12 plants per accession. To analyze the number of days to flowering only the average for each accession was recorded. The average yield per accession per location was calculated $\left(\mathrm{g} \mathrm{m}^{-2}\right)$, while 100 -seed weight $(\mathrm{g})$ was determined by weighing two random samples of each accession. Protein content (\%) was determined by the Kjeldahl method ${ }^{27}$ and calculated by multiplying the nitrogen content by 6.25 .

\section{Data analysis}

All the traits were compared per accession across all and for each one of the three locations (AUA, INIAV and UTAD). Per accession and location, 12 plants were considered as replicates. The evaluation of qualitative traits was determined by the frequencies of each trait. Descriptive statistics per quantitative trait and location were obtained using the summary statistics procedure in SPSS program version 8.0 (IBM SPSS, Inc., Chicago, IL, USA). For each trait, the minimum, maximum, mean and standard deviation, and coefficients of variation (CV) were calculated.

To estimate variance components of traits, a complete linear mixed model was used in the analysis of all the quantitative traits within and across the accessions and locations using the restricted maximum likelihood (REML) algorithm of SPSS program version 8.0. The heritability of each quantitative trait was calculated using the following equation: $\mathrm{H}^{2}=\left(\mathrm{s}_{\mathrm{g}}{ }^{2}\right) /\left[\mathrm{s}_{\mathrm{g}}{ }^{2}+\left(\mathrm{s}_{\mathrm{e}}{ }^{2} / r\right)\right]$, where $\mathrm{s}_{\mathrm{g}}{ }^{2}$ and $\mathrm{s}_{\mathrm{e}}{ }^{2}$ represent the genetic and residual variance for each trait and $r$ is the number of replicates of each accession. ${ }^{28}$

Pearson correlation coefficients between the different quantitative traits and locations were determined through SPSS program version 8.0 . To quantify the variation size due to 


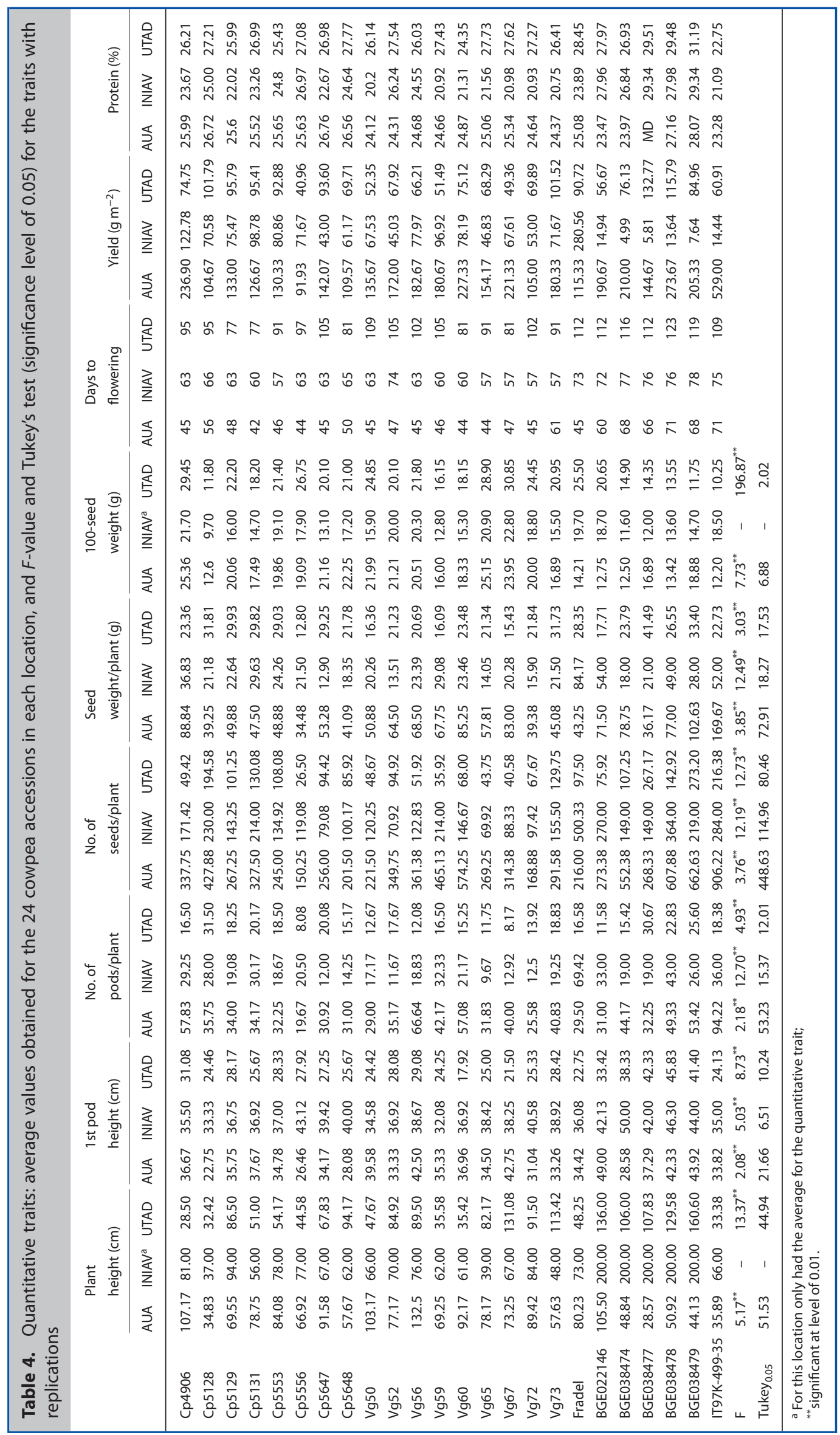


Table 5. Descriptive statistics for the nine quantitative traits studied, for each and all the three locations, for the 24 cowpea accessions

\begin{tabular}{|c|c|c|c|c|c|c|c|}
\hline Location & Trait & Min. & Max. & Mean & SD & CV (\%) & $\mathrm{H}^{2}$ \\
\hline \multirow[t]{9}{*}{ AUA } & Plant height $(\mathrm{cm})$ & 17.00 & 187.00 & 73.62 & 44.69 & 60.71 & 0.27 \\
\hline & 1st pod height $(\mathrm{cm})$ & 4.00 & 125.00 & 35.64 & 14.89 & 41.78 & 0.10 \\
\hline & No. of pods/plant & 1.00 & 166.00 & 39.14 & 30.47 & 77.80 & 0.10 \\
\hline & No. of seeds/plant & 13.00 & 1454.00 & 362.56 & 313.01 & 86.33 & 0.27 \\
\hline & Seed weight/plant (g) & 2.00 & 255.00 & 63.92 & 51.06 & 79.88 & 0.27 \\
\hline & 100-seed weight (g) & 5.00 & 33.30 & 18.55 & 5.57 & 30.05 & 0.49 \\
\hline & Days to flowering & 42 & 71 & 52.04 & 10.04 & 19.29 & \\
\hline & Yield $\left(\mathrm{g} \mathrm{m}^{-2}\right)$ & 91.93 & 529.00 & 179.29 & 88.59 & 49.41 & \\
\hline & Protein (\%) & 23.28 & 28.07 & 25.28 & 1.19 & 4.75 & \\
\hline \multirow[t]{9}{*}{ INIAV } & Plant height (cm) & 37.46 & 200.00 & 94.22 & 56.88 & 60.36 & MD \\
\hline & 1st pod height $(\mathrm{cm})$ & 24.00 & 55.00 & 38.12 & 5.75 & 15.08 & 0.29 \\
\hline & No. of pods/plant & 3.00 & 111.00 & 22.24 & 17.16 & 77.14 & 0.56 \\
\hline & No. of seeds/plant & 13.00 & 865.00 & 156.63 & 126.80 & 80.96 & 0.55 \\
\hline & Seed weight/plant (g) & 2.40 & 140.00 & 25.47 & 20.28 & 79.61 & 0.55 \\
\hline & 100-seed weight (g) & 9.70 & 22.80 & 16.68 & 3.48 & 20.88 & $M D$ \\
\hline & Days to flowering & 57 & 78 & 65.62 & 7.40 & 11.28 & \\
\hline & Yield $\left(\mathrm{g} \mathrm{m}^{-2}\right)$ & 4.99 & 280.56 & 65.46 & 56.05 & 85.52 & \\
\hline & Protein (\%) & 20.20 & 29.34 & 24.17 & 2.89 & 11.99 & \\
\hline \multirow[t]{9}{*}{ UTAD } & Plant height $(\mathrm{cm})$ & 10.00 & 200 & 77.43 & 40.03 & 62.31 & 0.51 \\
\hline & 1st pod height $(\mathrm{cm})$ & 8.00 & 58 & 28.53 & 9.85 & 34.53 & 0.43 \\
\hline & No. of pods/plant & 1.00 & 58 & 17.12 & 10.38 & 60.63 & 0.25 \\
\hline & No. of seeds/plant & 4.00 & 548 & 100.52 & 84.84 & 84.39 & 0.50 \\
\hline & Seed weight/plant (g) & 1.30 & 97.30 & 24.39 & 14.21 & 58.29 & 0.15 \\
\hline & 100-seed weight (g) & 10.00 & 31.00 & 20.33 & 5.73 & 28.16 & 0.99 \\
\hline & Days to flowering & 77 & 123 & 99.50 & 13.61 & 13.68 & \\
\hline & Yield $\left(\mathrm{g} \mathrm{m}^{-2}\right)$ & 40.96 & 132.77 & 78.54 & 22.48 & 28.63 & \\
\hline & Protein (\%) & 24.35 & 31.90 & 27.32 & 1.54 & 5.64 & \\
\hline \multirow[t]{9}{*}{ Total } & Plant height $(\mathrm{cm})$ & 10.00 & 200.00 & 76.26 & 46.93 & 61.54 & 0.15 \\
\hline & 1st pod height $(\mathrm{cm})$ & 4.00 & 125.00 & 33.93 & 11.76 & 34.66 & 0.09 \\
\hline & No. of pods/plant & 1.00 & 166.00 & 26.56 & 23.49 & 88.29 & 0.10 \\
\hline & No. of seeds/plant & 4.00 & 1454.00 & 193.56 & 219.17 & 99.90 & 0.17 \\
\hline & Seed weight/plant (g) & 1.00 & 255.00 & 36.09 & 25.62 & 98.70 & 0.12 \\
\hline & 100-seed weight $(\mathrm{g})$ & 5.00 & 33.30 & 14.33 & 9.26 & 64.62 & 0.54 \\
\hline & Days to flowering & 42 & 123 & 72.39 & 22.68 & 31.33 & \\
\hline & Yield $\left(\mathrm{g} \mathrm{m}^{-2}\right)$ & 4.99 & 529.00 & 107.76 & 79.67 & 73.91 & \\
\hline & Protein (\%) & 20.20 & 31.90 & 25.52 & 2.38 & 9.32 & \\
\hline
\end{tabular}

genotype $\times$ environment (location) interaction relative to main genotype variation, the quantitative parameters over locations were analyzed using a linear mixed model with the REML procedure of SPSS program version 8.0. The genotypes and genotype $\times$ environment interaction $(\mathrm{G} \times \mathrm{E})$ were considered as random effects and the locations as fixed effects. The results of this mixed model quantify the size of the $\mathrm{G} \times \mathrm{E}$ interaction relative to the genetic variance using the ratio $\sigma_{\text {ge }}^{2} / \sigma^{2}{ }_{g}$, where $\sigma_{\text {ge }}^{2}$ and $\sigma_{g}^{2}$ represent the genotype $\times$ genotype interaction and the genotype impact, respectively. Principal component analysis (PCA) was performed using MVSP version 3.22 statistical software. $^{29}$

\section{RESULTS AND DISCUSSION}

The environmental parameters or climatic data recorded in 2014 comparative to historical averages at the three locations (AUA, INIAV and UTAD) can be considered normal, suggesting that the data observed in this study reflect the plant performance in each location.

Qualitative traits are considered the most appropriate to determine a specific cultivar/variety because they are mostly genetically controlled, being independent from the environment. In this present study, the frequencies for each five qualitative traits studied were determined in regard to the three different locations (Table 3).

Growth habit presented some variation among locations, erect growth being the most common ( $47.4 \%$ and $86.9 \%$, respectively) in AUA and UTAD, whereas in INIAV semi-erect (79.17\%) was the most prevalent growth habit regarding the total accessions studied. For consumers and farmers, seed traits such as color seed and eye, seed size and seed coat are considered the most important traits of cowpea. ${ }^{30,31}$ In all locations, seeds had a predominant cream color, kidney shape and black eye (Table 3), in accordance with consumer preferences. ${ }^{22}$ These findings are in contrast to the results obtained by Negri et al. ${ }^{4}$ and Egbadzor et al.. ${ }^{24}$ who observed a higher 
Table 6. Estimates of variance components for genotypic variance and variance for genotype $\times$ environment and ratio of genotype $\times$ environment interaction variance to genetic variance for the five quantitative traits in 24 cowpea accessions

Source of variance

\begin{tabular}{|lccc|} 
& \multicolumn{3}{c|}{ Source of variance } \\
\cline { 2 - 4 } Trait & $\begin{array}{c}\text { Genotype } \\
\left(\sigma^{2} g\right)\end{array}$ & $\begin{array}{c}\text { Genotype } \times \text { environment } \\
\left(\sigma^{2}{ }_{\text {ge }}\right)\end{array}$ & $\sigma^{2}{ }_{\mathrm{ge}} / \sigma^{2}{ }_{\mathrm{g}}$ \\
\hline Plant height & 134 & 902.22 & 6.70 \\
1st pod height & 10.87 & 12.69 & 1.17 \\
No. of pods/plant & 85.64 & 23.19 & 0.27 \\
No. of seeds/plant & 5423.78 & 8104.40 & 1.49 \\
Seed weight/plant & 20.97 & 290.57 & 13.86 \\
\hline
\end{tabular}

variability in these two traits in cowpea accessions from Italy and Ghana.

Regarding the nine quantitative traits (Table 4), a high variability was observed in the number of days to flowering among the three locations. The average number of days to flowering was 52 (AUA), 65 (INIAV) and 99 (UTAD), with an average of 73.39 for the three environments (Table 5). This differentiation could be explained by the different temperature range observed in the three locations and also the different sowing dates in each location (Table 2). The INIAV sowing date was earlier than AUA and UTAD because among the three locations INIAV is the warmest, so it is important to sow early (Table 2). In general, cowpea accessions with the higher and the lower values were concordant; namely, accession BGE038478 presented the latest flowering in all locations whereas accession Cp5131 presented the earliest one (Table 4). The beginning of flowering has been considered an important trait in genotype selection for cowpea improvement. Indeed, Silva et al. ${ }^{32}$ referred to its negative correlation with seed production. Moreover, accessions with earlier flowering dates would be more interesting because this way cowpea plants are more likely to escape high temperatures, long water stress periods and low relative humidity. ${ }^{22}$ In fact, Hamidou et al. ${ }^{33}$ verified that there is a higher drought susceptibility in the flowering stage than in the vegetative stage of cowpea.

Variance analysis revealed significant differences, at a level of $1 \%$, between accessions for six quantitative traits (plant height, first pod height, number pods per plant, number seeds per plant, seed weight and 100-seed weight (Table 4).

Plant height of the accessions fluctuated particularly in each tested location, ranging from 10 to $200 \mathrm{~cm}$, with a mean value of 77.43 (Table 5). De Souza et al. ${ }^{34}$ previously reported similar maximum values for plant height in cowpea populations and a mean value of $164 \mathrm{~cm}$, whereas a mean value of $113.7 \mathrm{~cm}$ was reported by Basaran et al. ${ }^{35}$ In comparison, Abayomi et al. ${ }^{36}$ reported a maximum plant height of $59.12 \mathrm{~cm}$. A higher $C V$ value was calculated for plant height (61.54\%) than that reported by de de Souza et al., ${ }^{34}$ indicating the high variability of this trait among the accessions tested in this study.

The average value for the first pod height in the three environments was $33.93 \mathrm{~cm}$.

The extreme values of the three locations were observed in Cp5556 $(4 \mathrm{~cm})$ and BGE022146 $(125 \mathrm{~cm})$ accessions at the AUA location; at INIAV, the values ranged from $24 \mathrm{~cm}$ (Cp4906 and Vg 59 accessions) to $55 \mathrm{~cm}$ (BGE038478 accession), with an average of $38.12 \mathrm{~cm}$; and at UTAD from $8 \mathrm{~cm}$ (Vg 59 accession) to $58 \mathrm{~cm}$ (BGE038474 and BGE038478 accessions), with an average of $28.53 \mathrm{~cm}$ (Table 5).
In modern agriculture, one of the most important characteristics in grain legumes is the first pod height. Plants with compact growth and a great distance of the first pod from the ground are highly desirable, allowing increased sowing density, facilitating mechanical harvesting and benefiting seed quality, since contact with soil and therefore rotting of pods and seeds are avoided. The importance of first pod height was also previously reported by Silva et al., 32 who described a simple correlation between the first pod height and the number of seeds per plant.

High variability was presented for number of pods and seeds per plant. Specifically, number of pods per plant ranged from one (Fradel at AUA and Vg 67 at UTAD) to 166 (BGE038479 at AUA), with an average of 26.56 pods per plant; seeds per plant ranged from four (Cp5556 at UTAD) to 1454 (BGE038478 at AUA), with an average of 193.56 (Table 5). The mean number of pods per plant observed in this study, as well as the CV value, was higher than reported by de Souza et al. ${ }^{34}$ for Brazilian local cultivars and by Oliveira et al. ${ }^{37}$ Seed weight per plant was also characterized by high variability, ranging from 1 to $255 \mathrm{~g}$. All three traits studied that are related to seed yield production presented high CV values, while CV values for number of pods and seeds per plant were higher than these reported by Ajayi et al. ${ }^{38}$ for cowpea breeding lines. Hundred-seed weight ranged from to 5 to $33.3 \mathrm{~g}$, with an average of $18.52 \mathrm{~g}$, which was slightly higher than that reported by Perrino et al. ${ }^{39}$ among cowpea landraces originating from the Mediterranean region.

Concerning yield, average values were calculated and for this reason it was not possible to perform statistical analysis. The average yield of the three locations was $107.76 \mathrm{~g} \mathrm{~m}^{-2}$. In AUA, IT97K-499-35 had the highest yield $\left(529 \mathrm{~g} \mathrm{~m}^{-2}\right)$ and Cp5128 the lowest $\left(91.93 \mathrm{~g} \mathrm{~m}^{-2}\right)$, whereas in INIAV the yield varied between $4.99 \mathrm{~g} \mathrm{~m}^{-2}$ (BGE038474) and $280.56 \mathrm{~g} \mathrm{~m}^{-2}$ (Fradel). In UTAD yield ranged from $40.96 \mathrm{~g} \mathrm{~m}^{-2}$ (Cp5556) to $132.77 \mathrm{~g} \mathrm{~m}^{-2}$ (BGE038477). These results showed evidence of the good adaptation of some accessions to different environments, such as BGE038477 from Spain and Fradel from Portugal.

The parameters that presented higher heritability were different in the three locations: seed weight per plant (AUA), number of pods per plant (INIAV) and 100-seed weight (UTAD) (Table 5). The genetic variability transmitted from parents to their offspring is reflected by heritability. ${ }^{40}$ This parameter is very important because it indicates the possibility and extent to which improvement can change a trait by selection. ${ }^{40,41} \mathrm{~A}$ high heritability alone is not sufficient to perform an efficient selection in advanced generations unless accompanied by a substantial amount of genetic advance. ${ }^{40,42}$ The different heritability observed could be explained by the behavior of the accessions in the different locations, allowing an understanding of how the environment affects these traits.

Regarding all three locations, the protein content varied between 20.20\% (Vg50 in INIAV) and 31.90\% (BGE038478 in UTAD), with an average of $25.69 \%$. The lowest protein contents observed were $23.28 \%$ at AUA (IT97K-499-35), 20.20\% at INIAV (Vg50) and 24.35\% at UTAD (Vg60). BGE038478 showed the highest protein content in all three locations $(28.07 \%$ at AUA, $29.34 \%$ at INIAV and $31.90 \%$ at UTAD). The values of protein content obtained are in agreement with the reference values that have been previously given for cowpea. ${ }^{9,43,44}$

Correlation coefficients between the six quantitative traits and the three locations together are presented in Table 6. The number of pods per plant was correlated with the number of seeds per plant $(r=0.813, P=0.01)$ and with the seed weight per plant 
Table 7. Pearson correlation coefficients for the six quantitative traits, in all three locations, for the 24 cowpea accessions

\begin{tabular}{|c|c|c|c|c|c|c|}
\hline & Plant height & 1st pod height & No. of pods/plant & No. of seeds/plant & Seed weight/plant & 100 -seed weight \\
\hline Plant height & 1 & & & & & \\
\hline 1st pod height & $0.274^{* *}$ & 1 & & & & \\
\hline No. of pods/plant & 0.052 & $0.263^{* *}$ & 1 & & & \\
\hline No. of seeds/plant & 0.004 & $0.307^{* *}$ & $0.813^{* *}$ & 1 & & \\
\hline Seed weight/plant & 0.071 & $0.275^{* *}$ & $0.809^{* *}$ & $0.894^{* *}$ & 1 & \\
\hline 100 -seed weight & $0.189^{* *}$ & 0.021 & 0.001 & $-0.144^{* *}$ & 0.026 & 1 \\
\hline
\end{tabular}

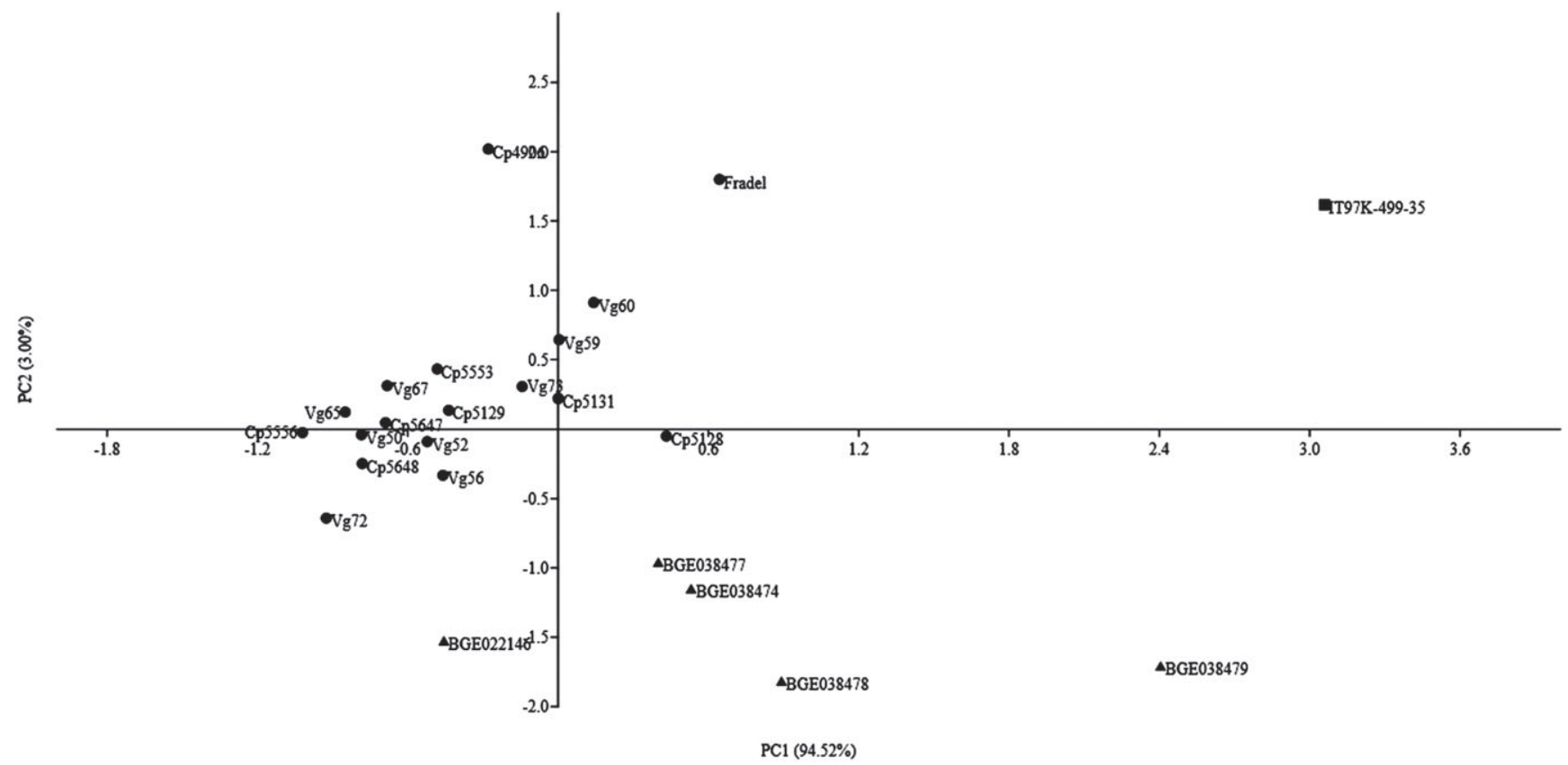

Figure 1. PCA of cowpea accessions in all three locations based on the eight quantitative traits measured (circles, Portuguese origin; triangles, Spanish origin; square, Nigerian origin).

$(r=0.809, P=0.01)$. This allows us to infer that the selection to increase the number of pods per plant favors seed weight and, consequently, productivity. These results confirm those obtained by Mohammed et al. ${ }^{45}$ Stoilova and Pereira ${ }^{22}$ and Silva et al., ${ }^{32}$ who state that one of the most important components for seed production for cowpea is the number of pods per plant. Number of seeds per plant was negatively correlated with the 100-seed weight $(r=-0.144, P=0.01)$, which shows that selection for increased number of seeds can induce a reduction in the 100-seed weight.

Four of the five quantitative traits (plant height, first pod height, number of seeds per plant and seed weight) revealed a higher $\mathrm{G} \times \mathrm{E}$ component than genetic variance component (Table 7). In general, an inverse relationship between $\sigma^{2}{ }_{g e} / \sigma_{g}^{2}$ ratio and heritability value was observed.

The first two principal components of PCA explained $97.52 \%$ $(P C 1=94.52 \%$ and $P C 2=3.00 \%$ ) of the total variation (Fig. 1 and Table 8). The major trait that contributed to the first component separation was the number of seeds per plant $(0.971)$, and to the second component plant height $(-0.548)$ and protein content (0.790) (Table 8). PCA allowed the discrimination of cowpea accessions based on their country of origin. Portuguese accessions were grouped mainly together in the second and third quadrant, while the Fradel variety and the reference line IT97K-499-35
Table 8. Eigen values, factor scores and contribution of the first two principal axes ( $\mathrm{PC} 1, \mathrm{PC} 2)$ to the variation of the 24 cowpea accessions

\begin{tabular}{|lcc|} 
& PC1 & PC2 \\
\hline Plant height & -0.056 & -0.548 \\
1st pod height & 0.007 & -0.102 \\
No. of pods/plant & 0.076 & 0.056 \\
No. of seeds/plant & 0.971 & -0.198 \\
Seed weight/plant & 0.128 & 0.130 \\
100-seed weight & -0.014 & 0.061 \\
Yield & 0.003 & -0.038 \\
Protein content & 0.180 & 0.790 \\
Eigen value & 14845.234 & 471.433 \\
Percentage (\%) & 94.518 & 3.002 \\
Cumulative (\%) & 94.518 & 97.519 \\
\hline
\end{tabular}

were separated at higher distance (first quadrant). In addition, the Cp4906 accession, was separated from the other Portuguese accessions. This accession was the only one collected near the coast (Atlantic Ocean). Four of the five Spanish accessions were grouped in the fourth quadrant. 


\section{CONCLUSIONS}

The present study highlights the high genetic diversity existing in the Iberian Peninsula cowpea genetic resources and useful knowledge about its breeding value. Seeds per plant is the trait that should be used primarily for plant selection. A clear distinction was observed between landraces and the reference samples, variety and breeding line. Moreover, the set of accessions with Spanish and Portuguese origin was discriminated in PCA, suggesting a specific gene pool structure.

$\mathrm{G} \times \mathrm{E}$ interaction, important yield components such as number of pods and seeds per plant and seed weight encompass variation between accessions. This variability reveals the potential of this germplasm for breeding programs to be conducted in different environments.

The accessions BGE038477 and BGE038478 from Spain and Cp5553 and Vg60 from Portugal have already been included in a cowpea breeding program.

\section{ACKNOWLEDGEMENTS}

The research work was funded by the European Union's Seventh Framework Programme for Research, Technological Development and Demonstration under grant agreement $n^{\circ} 613781$, project EUROLEGUME. The authors acknowledge the AUA Laboratory of General and Agricultural Meteorology for the data provided to us and the University of California Riverside cowpea researchers for providing breeding line IT97K-499-35.

\section{REFERENCES}

1 Pasquet RS, Allozyme diversity of cultivated cowpea Vigna unguiculata (L.) Walp. Theor Appl Genet 101:211-219 (2000).

2 Coulibaly S, Pasquet RS, Papa R and Gepts P, AFLP analysis of the phenetic organization and genetic diversity of Vigna unguiculata (L.) Walp. reveals extensive gene flow between wild and domesticated types. Theor Appl Genet 104:358-366 (2002).

3 Steele WM, Cowpea, Vigna unguiculata (Leguminosae Papillionatae), in Evolution of Crop Plants, ed. by Simmonds NW. Longman, London, pp. 183-185 (1976).

4 Negri V, Tosti N, Falcinelli $\mathrm{M}$ and Veronesi F, Characterization of thirteen cowpea landraces from Umbria (Italy): strategy for their conservation and promotion. Genet Resour Crop Evol 47:141-146 (2000).

5 Tosti $\mathrm{N}$ and Negri $\mathrm{V}$, On-going on-farm microevolutionary processes in neighbouring cowpea landraces revealed by molecular markers. Theor Appl Genet 110:1275-1283 (2005).

6 Tan H, Tie M, Luo Q, Zhu Y, Lai J and Li H, A review of molecular markers applied in cowpea (Vigna unguiculata). J Life Sci 6:1190-1199 (2012).

7 FAOSTAT, Food and Agriculture Organization of the United Nations - Statistics Division. [Online]. Available: http://faostat3 .fao.org/browse/Q/QC/E [6 March 2017].

8 Singh BB, Ajeigbe HA, Tarawali SA, Fernandez-Rivera S and Abubakar $M$, Improving the production and utilization of cowpea as food and fodder. F Crop Res 84:169-177 (2003).

9 Timko MP, Ehlers JD and Roberts P, Cowpea, in Genome mapping and molecular breeding in plants: Pulses, sugar and tuber crops, ed. by Kole C. Springer, Berlin, pp. 49-67 (2007).

10 Boukar O, Massawe F, Muranaka S, Franco J, Maziya-Dixon B, Singh B et al., Evaluation of cowpea germplasm lines for protein and mineral concentrations in grains. Plant Genet Resour 9:512-522 (2011).

11 Agbicodo EM, Genetic analysis of abiotic and biotic resistance in cowpea [Vigna unguiculata (L.) Walp.]. Dissertation, Wageningen University (2009)

12 Fraire-Velázquez $\mathrm{S}$ and Balderas-Hernández VE, Abiotic stress in plants and metabolic responses, in Abiotic Stress: Plant Responses and Applications in Agriculture, ed. by Vahdati K and Leslie C, InTech, Rijeka, Croatia, pp. 25-48 (2013).
13 Daryanto S, Wang $L$ and Jacinthe PA, Global synthesis of drought effects on food legume production. PLoS One 10:e0127401 (2015).

14 Hall $A E$, Breeding for adaptation to drought and heat in cowpea. Eur J Agron 21:447-454 (2004).

15 Kwapata $M B$ and Hall $A E$, Effects of moisture regime and phosphorus on mycorrhizal infection, nutrient uptake and growth of cowpeas (Vigna unguiculata (L.) Walp.). F Crop Res 12:241-250 (1985).

16 Lazaridi E, Ntatsi G, Savvas D and Bebeli PJ, Diversity in cowpea (Vigna unguiculata (L.) Walp.) local populations from Greece. Genet Resour Crop Evol. https://doi.org/10.1007/s10722-016-0452-6 (2016).

17 Tosti N and Negri V, Efficiency of three PCR-based markers in assessing genetic variation among cowpea (Vigna unguiculata subsp. unguiculata) landraces. Genome 45:268-275 (2002).

18 Eagles HA and Lothrop JE, Highland maize from central Mexico: Its origin, characteristics, and use in breeding programs. Crop Sci 34:11-19 (1993).

19 Zeven AC, Landraces: A review of definitions and classifications. Euphytica 104:127-139 (1998).

20 European Commission, Trade: Export Helpdesk: EU Customs Union. European Commission. [Online]. Available: http://exporthelp .europa.eu/thdapp/index.htm [7 March 2017].

21 Adewale BD, Adeigbe $\mathrm{OO}$ and Aremu C, Genetic distance and diversity among some cowpea (Vigna unguiculata L. Walp) genotypes. Int J Res Plant Sci 1:9-14 (2011).

22 Stoilova T and Pereira G, Assessment of the genetic diversity in a germplasm collection of cowpea (Vigna unguiculata (L.) Walp.) using morphological traits. Afr J Agric Res 8:208-215 (2013).

23 Cardona-Ayala CE, Araméndiz-Tais $T$ and Jarma-Orozco A, Genetic variability in cowpea beans lines (Vigna unguiculata L. Walp.). Agronomía 21:7-18 (2013).

24 Egbadzor KF, Dadoza M, Danquah EY, Yeboah M, Offei SK and Ofori K, Genetic control of seed size in cowpea (Vigna unguiculata (L.) Walp). Int J Agric Sci 5:367-371 (2013).

25 Egbadzor KF, Danquah EY, Ofori K, Yeboah M and Offei SK, Diversity in 118 cowpea [Vigna unguiculata (L.) Walp.] accessions assessed with 16 morphological traits. Int J Plant Breed Genet 8:13-24 (2014).

26 IBPGR, Descriptors for cowpea. International Board for Plant Genetic Resources, Rome (1982).

27 AOAC, Official methods of analysis (15th edn). AOAC, Arlington, VA (1990).

28 Gitonga VW, Koning-Boucoiran CFS, Verlinden K, Dolstra O, Visser RGF, Maliepaard C et al., Genetic variation, heritability and genotype by environment interaction of morphological traits in a tetraploid rose population. BMC Genet 15:146 (2014).

29 Kovach WL. 2010. MVSP: A multivariate statistical package for Windows, version 3.2. Kovach Computing Services, Pentraeth, UK.

30 Mustapha Y, Inheritance of seed colour in cowpea (Vigna unguiculata (L.) Walp). Int J Pure App/ Sci 2:1 -9 (2008).

31 Egbadzor KF, Yeboah DK, Gamedoagbao SB, Offei SK, Danquah EY and Ofori $\mathrm{K}$, Inheritance of seed coat colour in cowpea (Vigna unguiculata (L.) Walp). Int J Plant Breed Genet 8:35-43 (2014).

32 Silva AC, Morais OM, Santos JL, D'Arede LO, Silva CJ and Rocha M, Estimativa de parâmetros genéticos em Vigna unguiculata. Soc Cienc Agrar Port 37:399-407 (2014).

33 Hamidou F, Zombre G and Braconnier S, Physiological and biochemical responses of cowpea genotypes to water stress under glasshouse and field conditions. J Agron Crop Sci 193:229-237 (2007).

34 de Souza CLC, Lopes AC, Gomes LRF, Rocha MMa and Silva EM, Variability and correlations in cowpea populations for green-grain production. Crop Breed Appl Biotechnol 7:262-269 (2007).

35 Basaran U, Ayan I, Acar Z, Mut H and Asci OO, Seed yield and agronomic parameters of cowpea (Vigna unguiculata L.) genotypes grown in the Black Sea region of Turkey. Afr J Biotechnol 10:13461-13464 (2011).

36 Abayomi YA, Ajibade TV, Sammuel OF and Sa'adudeen BF, Growth and yield responses of cowpea (Vigna unguiculata (L.) Walp) genotypes to nitrogen fertilizer (NPK) application in the Southern Guinea Savanna zone of Nigeria. Asian J Plant Sci 7:170-176 (2008).

37 Oliveira E, Mattar EPL, Araújo ML, Jesus JCS, Nagy ACG and Santos VB, Descrição de cultivares locais de feijão-caupi coletados na microrregião Cruzeiro do Sul, Acre, Brasil. Acta Amaz 45:243-254 (2015).

38 Ajayi AT, Adekola MO, Taiwo BH and Azuh VO, Character Expression and Differences in yield potential of ten genotypes of cowpea (Vigna unguiculata L. Walp). Int J Plant Res 4:63-71 (2014). 
39 Perrino P, Laghetti G, Spagnoletti-Zeuli PL and Monti LM, Diversification of cowpea in the Mediterranean and other centres of cultivation. Genet Resour Crop Evol 4:121 - 132 (1993).

40 Mishra P and Singh P, Genetic variability, heritability, genetic advance, correlation coefficient and path analysis in gladiolus. IOSR J Agric Vet Sci 7:23-26 (2014).

41 Robinson HF, Comstock RE and Harvey PH, Estimates of heritability and the degree of dominance in corn. Agron J 41:353-359 (1949).

42 Jonhson HW, Robinson HF and Comstock RE, Estimates of genetic and environmental variability in soybean. Agron J 47:274-318 (1955).

43 Nielsen SS, Brandt WE and Singh BB, Genetic variability for nutritional composition and cooking time of improved cowpea lines. Crop Sci 33:469-472 (1993).
44 Singh BB, Recent genetic studies in cowpea, in Challenges and opportunities for enhancing sustainable cowpea production. Proceedings of the World Cowpea Conference III held at the International Institute of Tropical Agriculture (IITA), ed. by Fatokun CA, Tarawali SA, Singh BB, Kormawa PM and Tamo M. Ibadan, Nigeria, pp. 3-13 (2002).

45 Mohammed MS, Russom Z and Abdul SD, Inheritance of hairiness and pod shattering, heritability and correlation studies in crosses between cultivated cowpea (Vigna unguiculata (L.) Walp.) and its wild (var. pubescens) relative. Euphytica 171:397-407 (2010). 